International Journal of Behavioral Research \& Psychology (IJBRP)

ISSN 2332-3000

\title{
The Core Self in Psychoanalytic Literature and Its Benign and Ideal Dimensions
}

\author{
Sollars F R
}

Research Article

Michigan School of Professional Psychology, 26811 Orchard Lake Road, Farmington Hills, MI 48334, USA.

\section{Abstract}

The author garners support in psychoanalytic literature for the conceptualization of a core self with transcendent properties and the capacity to experience a communal sense of union. This core self is thought to contain a dual track notion of self/other experience in which the boundaries of self and other are paradoxically differentiated and yet identical. Rather than pathological, this self/no-self experience is unitive and unambivalent and leads to ecstatic experience of transcendence and communion with benign capacities. The author draws from psychoanalysis and from Plotinian philosophy to frame the core self with its loving capacities as ultimately benign and ideal and as originary experience embedded in our deepest nature. All character defects, faults and malevolent affects and experience are considered permutations of the positive elements of core self experience. The author suggests a goal of psychoanalysis can be the liberation of this core self from the shroud of negative affects and character faults. Through the containment and transformation of negative affect and experience, the eventual discovery of the numinous sublime qualities of the core self may emerge.

\section{*Corresponding Author:}

Franklin R. Sollars,

Michigan School of Professional Psychology,

26811 Orchard Lake Road, Farmington Hills, MI 48334, USA.

Tel: +1(248)705-3798

E-mail: Fsollars@mispp.edu

Received: April 09, 2014

Accepted: May 08, 2014

Published: May 12, 2014

Citation: Sollars F R (2014) The Core Self in Psychoanalytic Literature and Its Benign and Ideal Dimensions. Int J Behav Res Psychol. 2(4), 4046. doi: http://dx.doi.org/10.19070/2332-3000-140008

Copyright: Sollars F R ${ }^{\odot}$ 2014. This is an open-access article distributed under the terms of the Creative Commons Attribution License, which permits unrestricted use, distribution and reproduction in any medium, provided the original author and source are credited.

\section{Introduction}

This paper has three fundamental goals: first to provide a framework for the conceptualization of a core self by reviewing psychoanalytic authors who hold ideas analogous to this concept. Second, by using their positions as a base, to extend the concept to embrace a positive ideal dimension to the core self. Third, I will also suggest some elemental techniques to transform negative affect and experience which may be used in the liberation of our core self.

By core self I mean a self that includes self and non -self paradoxically interposed - a self or subject that is inside the other and the other inside the self. This self is also constituted by and rests in a communal experience of union. Taking the positive ideals inherent in the Bionion tradition and using Plotinian philosophy as framework, I propose that this inherent communal experience or sense of union contains the positive and ideal elements of love, benevolence, capacity for concern, and all unambivalent benign aspects of human affect and experience. This self experience embedded in communal union is the center of ourbeing with its array of positive loving aspects. It is the sun behind the cloud of our de- fensive functioning and our negative character traits.

The freeing of and revealing of this core self from the shroud of defensive functioning could also be thought of as a liberation psychology. The goal here is ultimately the liberation of the unitive, vibrant and ecstatic core self. The classical defenses, combined with negative character traits and hostile affect,analogously form the shroud that covers the divine spark and the pearl beyond price or core self referred to in Gnostic lore.

\section{A Third Perspective}

Some authors such as Winnicot (1965) and Kohut (1977) have emphasized the core selfs inherent positive elements but do not reflect its formal ideal aspects in the Platonic sense. Others such as Bion (1970), Grotstein (1979 a, 1979 b) and Eigen (1998) emphasize the core selfs ideal dimension but see transcendence as a dualistic proposition, that is comprised of both negative and positive formal ideals in the Platonic sense. I am suggesting a thirdapproach - using neo Platonic thought to frame and affirm a position that our core selves are ultimately positive in the formal ideal sense, unambivalent at base, and that this can inform our clinical practice and move it in a positive transcendent direction. Grotstein's (1979 a, 1979 b) position, of transcendent formal elements to a core self, seems closest to mine. However, as to his view on whether the formal dimension of self is ultimately positive, Grotstein wavers. At times he infers the background object or ultimate experience is benevolent and Godlike. At other times he suggests that a "death instinct organization" (undifferentiated from the "life instinct organization") and the "epistemological organization" is the ultimate ground of existence - granting cruelty transcendent metaphysical properties equal to benevolence, thus asserting a dualistic ideal perspective.

This core self $\mathrm{I}$ am proffering is unitive at base and has to be rescued from the encumbrances of character defects and defenses to participate in the external project of liberation of others. I will suggest that the core selfs interiority contains a vessel- like channel to the alterity of the other. This channel promotes a felt sense of 
oneness with the otherthattranscends the sense of separation and alienation. Like a stone thrown in the water, this connection with the unity of others promotes healing,felt empathy and compassion, and encourages others to leave behind the isolating walls of separation and alienation.

\section{Paradoxical and transcendent elements of the Core Self}

The core self contains or expresses many paradoxes:e.g.; self/ non self, fluidity/stability, interiority / exteriority, subjectivity /objectivity, multivariance/coherence, transcendence/ immanence. In attempting to understand deeper levels of being and the self, it is difficult to sum up these elements in an elegant manner. Hopefully, as I review theories of self which bear resemblance to the core self I postulate here and elucidate these paradoxes described above, a picture will form that has some semblance of a pictorial contour or form that captures the meaning which the core self can metaphorically represent.

Both psychoanalytic and spiritual perspectives recognize within their traditions something analogous to the existence of a core self and, within it, a dynamic tension between both intrinsic coherence and stability and firm and fluid boundaries between self and other. This paradoxical balance accounts for the characteristic transpersonal qualities of the core self. When the dualities of self and other are not denied but instead bridged, there is a simultaneous capacity for empathic identification and clear perspective- an ecstatic union of affect and vision that makes for a rich wisdom and ethicality. This clarity of vision permits malevolence, parochialism, selfishness, vanity and other such character-denying traits to be seen for what they are as life denying, defensive, and self defeating to inspired living from our heart. When real understanding and empathy are possible, appearances become less important, and rules and laws are secondary to the dictates of the heart. The other rests inside us in a felt, not intellectualized, capacity. There is an immediate awareness of our mutual identity and an empathic resonance although self and other remain physically separate. Referencing Meister Eckhart, Gargiulo (2004) elaborates on the notion of interiorityas both exteriority and extended identification. The world exists and is constantly recreated at the edge of the me / not-me. Such internality, which Eckhart speaks of and which psychoanalysis is likewise aware of, locates the knowing other as inside the self, as well as the known-other, the world, as simultaneously internal and external (p.50).

I want to make it clear that the transpersonal position of the core self is not the same thing as a loss of self; it is not due to weak ego boundaries, or to poor reality testing in an ego impaired by overwhelming negative affect or negative internalized objects. On the contrary, liberation of the core self depends on ego strength. An overwhelmed ego defends itself as long as it can and then capitulates. Only when self-defensive anxieties, impulses, and wishes have been significantly resolved can the ego surrender itself to the core self, with its firm but fluid boundaries between self and other.

\section{Psychoanalytic authors'perspectives analogous to the core self}

Marion Milner (1952) in her early work gives play to the notion of self / non-self fluidity, considering it not as a pathological regression but rather as a state of abundance with provisional aspects \{life affirming and restorative properties $\}$ that aid in self and object transformation (p. 188). Milner was herself something of a psychoanalytic mystic who actively pursued what I am calling spiritual goals. She soughtto overcome the boundaries between self and other and was able to articulate the self/other paradoxical overlap at a much earlier time than were most analysts.

Winnicott's notion of the true self and the core self have many elements in common. Both selves have in common their authenticity and a seat of inspiration that belies and transcends the defensive experience of the lesser or, to Winnicott, the false self (1965). Winnicott also suggests that the true self is fundamentally morally compassed; that is, it carries a tendency for the development of guilt and the capacity for concern (1965, p. 25). Winnicott's concept of aggression also supports the spiritual view that the core self is ethical and benign. For Winnicott (in contradistinction to the dual instinct theory of the later Freud), aggression was not an independent instinct. Winnicott equated it with activity and the life force and considered its primary function a benign one, except to the extent that it is distorted into destruction by a less than facilitating environment. As Greenberg and Mitchell (1983) describe his view: "Aggression is a need for something in the external environment for the self to struggle with and bump up against. The aggression or 'destruction' in Winnicott's late work on object usage is thus an innocent, nonbelligerent desire for engagement," (p. 206). For Winnicott, therefore, the core self is not a dark and seething cauldron but a lively seeker of an intimate connection. Winnicott intimates fluidity of self / non-self engagement through his concept of potential or transitional space. Transitional space is a metaphor for two simultaneous experiences- the experience of the self and the experience of evoking the other within the self. Because it is neither purely subjective nor purely objective but rather contains elements of both qualities, Winnicott recognized the transitional realm as inherently paradoxical. In his persistent focus on this paradox, he was seeking a perspective that could transcend the dichotomy between objectivity and subjectivity and honor "a third area of human living, one neither inside the individual nor outside in the world of shared reality" (1971, p. 110). Elaborating on his version of a healthy self Winnicott states, "This is the place I have set out to examine, the separation which is not a separation but a form of union" (1971, p.115). Winnicottadumbrates and intimates a dual union and transcendent quality to his true self although it is not well developed.

Christopher Bollas is another psychoanalyst who addresses issues of similarity to the core self. Bollas speaks of the human idiom, which he sees as the directional compass built into our existence or the progressive articulation of the true self through the use of objects in our environment. He defines the human idiom thusly: "The idiom of a person refers to the unique nucleus of each individual, a figuration of being that is like a kernel that can, under favourable circumstances, evolve and articulate" (1989, p. 212). Throughout Bollas' writing one can see shades of Jung, as in the articulation of the human idiom, which moves us in providential direction towards destiny. This seems to embrace elements of both Jung's self archetype and histranscendent function. While Bollas' human idiom seems an articulation of the true self with its capacity for concern, which can be viewed as providential, it lacks much of the transcendent and transpersonal qualities of other writers such as Bion, Grotstein, Eigen, and Gargiulo.

Jung's (1953) correlate of what I am calling the core self was the Self, with a capital S. Jungian archetypes are inherited, innate, and are a priori modes of perception linked to instincts which regulate perception and are common to all mankind. The Self is an archetype and the organizing center of the personality. It organizes, orders, and directs the personality toward self -realization. It 
balances the conscious and unconscious minds and is responsible for the transcendent function of harmonizing opposing trends within the personality. These opposing trends or polarizations in the personality such as wishes for cooperation and competition are usually considered dualities. For Jung these dualities create a dynamic state of tension which drives the personality rather than elements which, per force, remain debilitating by the tension they create. In Jung's ideal system there is containment of opposites, and darkness in the personality is considered vital and something not to be eradicated by the light. While there is a "golden" element to the shadow which, for example, can often be discovered in the darkness, much of Jung's work is a balance of the psyche including: conscious and unconscious elements, ego and shadow, and darkness and light.

Open to and influenced by the collective unconscious, which can be described as the matrix of inherited mythology and thinking processes in general, the Self archetype is deeply interconnected with others and with all of life while still maintaining its individuality. The ultimate goal of the developing personality, Jung believed, is through individuation and integration to educe and embrace the Self.

Heinz Kohut (1984) postulated a version of the self, analogous to the core self, called the "healthy self". Kohut posits a developmental progression in humans that proceeds toward fulfillment unless uninterrupted by traumatic experience $(1984,1977)$. He suggests that the healthy self will, in spite of traumatic experiences, "mobilize its striving to complete its development - that is, it will try again to establish an uninterrupted tension arc from basic ambitions, via basic talents and skills, towards basic ideals. The tension arc is the dynamic essence of the complete, non-defective self; it is a conceptualization of the structure whose establishment makes possible a creative, productive, fulfilling life" (1984, pp. 4, $5)$.

As in Bollas' and Jung's writings, Kohut's view posits that there is a human essence that strives to be productive, creative and fulfilled. The healthy self is a structure that exists from birth - a fundamental aspect of the self, a human essence. It is sturdy and resilient and not easily subject to fragmentation or disruption. A healthy self, Kohut says, "is a structure that - except perhaps as an outcome of the most severe forms of traumatization such as prolonged confinement in concentration camps and other protracted dehumanizing experiences-is not prone to become fragmented, or disharmonious during maturity, at least not severely and/or for long periods of time" (Kohut 1984, p. 70).

Kohut's notion of a healthy self contains the idea of a fluid and empathic boundary between self and other. Kohut, speaking of analysis and the liberation of the healthy self states that "The third step -- the essential one because it defines the aim and the result of the cure -- is the opening of a path of empathy between self and object, specifically the establishment of empathic in-tuneness between self and self object on a mature adult level. This new channel of empathy permanently takes the place of the formerly repressed or split-off archaic narcissistic relationship..." (1984 pp, 65-66.) Kohut's healthy self, also termedthe nuclear self, is central in his psychic system and its movement towards a creative, productive, and fulfilling life provides a providential element to his notion of self. His notion of healthy narcissistic development, which leads to a fulfilling life unless interrupted by trauma, also results in powerful empathic attunement and appreciation of the other. However, he does not see the other in the self and the self in the other in such a radical way as Bion, Gargiulo, Eigen, and I.

\section{Bion's Platonic idealism and his psychoanalytic lineage}

WifredBion (1962, 1963, 1965, 1966, 1970), one of psychoanalysis' most novel and extraordinary thinkers, provided a new metapsychology for psychoanalysis. He integrated and condensed (some may say conflated) Kant's thing in itself, Plato's concept of the forms, and an ideal conception of God through the deification of the two former theoretical positions.

Kantsthing in itself is the objective world that exists independently apart from our cognition and senses. This thing in itself, or noumenonal objective world, Kant placed in opposition to the phenomenal world which can be known and is an experience of mind. Plato's theory of the forms is a dualistic philosophy which suggests that the world of ideas, which Plato thought of as forms, has a greater reality than the material world. These forms could be drawn out of the formal or ideal world and into the mind and made material. The forms like Kant's thing-in-itself exist outside of our individual minds and thus have a preexistent quality.

Bion's condensation of Kantian and Platonic elements gave us the concept of "O" ororiginal experience. Bion's "O" is ubiquitous within, through and around us. The "O" contains what Bion called Beta elements. These Beta elements can be seen as analogous to Plato's forms or thoughts and that our mind, as a container, has not yet been able to metabolize and change into cognition.

Bion's famous rendezvous with " $\mathrm{O}$ " connects us with " $\mathrm{O}$ " in its transcendence and the "other" in a state of union. Bion placed a greater emphasis, in his later theorizing, with faith or immediate experience than he did rational understanding. Understanding "O" through rational functions was always a provisional myth or falsity which impeded "truth in "O". The "O" which faith embraces, Grotstein referencing Bion suggests is: our Truing "O" which must, through us, constantly intersect with its counterpart, the "O" of the Other (1981, p.55).

I believe this notion that the experience of "O" within us constantly intersects with the "O" of the Other unsettles the subject /object, interior/exterior, and self/other dichotomies and speaks of shared originary experience within and between all of us. It speaks of an inherent unity that we all share that can be recognized to be inherent in the conception of the core self. Bion (1970) in his later work equated the originary experience of "O" with the ideal of the Godhead. Forsaking the "miscreant container" or the ego as the ultimate self's expression he thought of the self more as the background originary subject/object of experience. The self seemed transcendent. Grotstein on Bion states: "I"ness consists, furthermore in a prismatic refraction of the emanations of this Godhead... (Grotstein, p. 505).

James Grotstein (1979a, 1979b, 2000) is perhaps WifredBion's foremost student. Like any good student he extended some of his teacher's ideas and challenged others.

He embraces Bion's Platonism but Grotstein places emphasis on the ineffable subject - the Dreamer who "dreams the dream". The ineffable subject, the dreamer of dreams, is always subjective and never objectively experienced. Grotstein's ineffable subject is "autochthonous," "signifying the fantasy that self and object are created entirely from and by the self" (Grotstein 1997 p. 403) 
while his phenomenal subject is the one who understands the dream and engages alterity (otherness). Grotstein's condensation of the ineffable subject of experience and the phenomenal subject engaged in alterity embraces the dual track notion of subject and object unity. He accomplishes this while suggesting it is not a pathological regression but rather a progression of consciousness. Transcendence embraces the numinous or wonderment and awe of participating in being.

Michael Eigen $(1983,1998)$ is another in the line of Bion who speaks of the raw experience of "O" in both its ideal, splendorous and horrific forms. Eigen (1983) also references a dual track self. He offers the term dual union to refer to the simultaneous presence of these two aspects of the self/other experience -- the experience of distinction, and the experience of union. Eigen believes that this basic experiential structure of dual union is characteristic of the self across all of its developmental levels.

Therefore, neither separateness nor union is a bedrock construct of human experience. It is perhaps more appropriate to speak of a two-in-oneness or one-in-twoness. Pure merger and isolation are abstract terms which do not characterize living experience. Areas of union and distinction occur together, with one or the other emphasized more in a given situation. In this context, Christian conceptions of a triune God or communion (co-union) appear to reflect a genuine advance in mystical and psychological description. Here a sense of division and union coexist fully, neither being possible without the other. Whatever its theological function, this kind of formulation expresses the basic structural requirements that a theory of the self (or ego) must meet (Eigen,1983 pgs 423, 424).

Eigen (2004) in a later work also points to a transcendent ideal aspect of the self which is unambivalent, pure and beatific at the heart of the self.

\section{Yet something claws at the innards, a vision. Radiance. Light. There does seem to be something unambivalent at the core-perhaps what is meant by calling the soul pure. For example, mystical Judaism affirms there is a point of the soul ever pure in contact with God. This, even though the empirical self or soul is quite impure [p.166]).}

Thus Eigen not only begins to embrace a notion of unambivalence and purity he places it precisely at our deepest center and uses "core" as the analogy.

Bion, Grotstein and Eigen embrace the notion of Platonic forms and relate these concepts to "O" or original experience. Bion's idea, to which Grotstein adheres, is that psychosis and mental illness accrue from the mind's inability to embrace and "alpha-betaize" the unthought thoughts that exist as sensory experience impinging on the mind's awaiting containment and eventual release. Sensory experience is transformed into beta elements and then into alpha elements or secondary process and the forms are then brought to life. When the sensory experience and beta elements cannot be contained and metabolized this inability creates conflict and possible psychosis. It is as if Bion's "organ mind" that contains and metabolizes thought (forms) functions as a traffic system. The forms press and push for metabolization and when they fail, or the traffic light is on red, we have illness.

Bion's use of Plato's theory of forms can be confusing as it relates to ideal or perfect forms. One use of the term ideal relates to the notion that ultimate reality is made up of ideas or conscious- ness. The second use implies a perfect or very high standard one may aspire to embrace. In this portion of the paper, the use of the term ideal is meant to represent a perfect standard or perfect representation. For Plato all forms had an ideal or perfect representation. Bion uses the term in a rather bi-polar manner. He suggests that there are negative as well as positive ideal representations of things and concepts. On one hand Bion postulates that the forms can be ideals of negative variety. Bion(1969) states: "The Platonic theory of Forms and the Christian dogma of the Incarnation imply absolute essence which I wish to postulate as a universal quality of phenomena such as 'panic', 'anxiety', 'fear', 'love' (p. 89). These essences suggest that formal ideals are negative as well as positive. At other times he proffers that the forms are Messianic rather than negative ideals and suggests the main problem with the psyche is that it cannot contain the powerful messianic ecstatic quality of the forms. The container cannot contain the forms considered to be beta elements and thus disperses them. It is as if we are only receiving the perfect forms of God and because we cannot metabolize them (the Messiah) we are left with mental illness.

\section{The Monad and the Unity of “ $O$ " beyond duality}

For Bion, Grotstien, and Eigen who follow, the forms have ideal positive and negative dimensions and illness accrues from our difficulty in embracing and containing them. The healthy personality then contains an array of forms or thoughts from ideal benign to ideal nefarious or malevolent ones. I would like to suggest an even more ambitious ideal for the psychoanalytic project, rather than containment of the array of forms from the horrific to the sublime, I suggest the goal could be the discovery within each of us of the ideal positive aspects of "O" which, I submit, always lays waiting for liberation from within any negative experience of " $O$." My proposition is that the ultimate "O" is the ideal "O" that is in close proximity to the divine as the third century philosopher Plotinus (1962) might suggest.

Plotinus wasone of the major philosophers of the ancient world, a translator of Plato, andperhaps the foremost Neo-Platonic thinker. (I wish to reiterate here that the psychoanalytic tree of Bion, Grotstien, Eigen and others of this ilk have Platonism embedded in their metapsychology.) Plotinus placed a great emphasis on ideal benevolent and divine foundation of Plato's idealism. The ultimate truth and metaphysical existence for Plotinus is the divinity of the monad or Godhead, and our world or experience of appearances is just a distortion. For Plotinus, we actually live Plato's allegory of the cave and only see the sun's reflection on its wall. The sun is the Godhead and we have a great deal of difficulty believing in its realty, instead seeing mostly its shadow.The shadow is here not merely the world of illusion of our material existence but also something akin to Jung's shadow or the negative experience (appearance) of projected hate, envy, greed and so forth that accrues from character defenseswhich shroud the core self and benign peaceful existence.

For Plotinus, Plato's formalistic idealism begins in the one, or Monad, although to say "begins" is already a distortion since it is beyond time and causality. The Monad is the Divine essence of all. It is perfect in love and wisdom and unites everything and everyone. Plotinus speaks of emanations. Emanations can be thought of as the Monad's diffusion of itself. That is, there is more distortion the further away from the source emanations devolve, i.e. the less divine and the more negative. Thus, horrific forms of experience can be thought of as having separated out as emanations from the source of the monad and perturbed into more negative 
forms. In my estimation the horrific forms of malevolence and cruelty are abjectly separated and distorted forms of the Monad. Ultimate unambivalent, divine "O," analogous to the Godhead, on the other hand, rests within the "heart" or deeper psyche of all of us - our core self.

Psychoanalysis can aid in the reclamation of the "Original ' $O$ ' "of the Monad from the dualistic perturbation of "O" into more negative forms. The ultimate aim then of psychoanalysis, from this perspective, is not merely the containment of both good and bad ideals of distorted forms, but the transformation of the negative back into positive. Hate, for example, can be seen as love outraged. Envy can be a distortion of admiration, hubris a distortion of self esteem and so forth. For Plotinus the individual soul is a lower irradiation of the divine but as such contains a trace of the divine that holistically contains all of the divine. Hence, herein lays my equation of the core self with the Kabala's notion of the divine spark of the soul and the Gnostic's pearl beyond price.

The soul's ultimate reality is unambivalent, sublime and connected with the monad. It is that which understands our inherent innersubjective connection to the other and the "All" and experiences this truth, albeit mostly unconsciously. If we can experience the light of the unambivalent sublime, contain it and not shrink from it, we can transcend the world of appearances (divisiveness, separateness, egoism, malevolence) and experience the monad's inherent love and ecstatic relational capacities embedded in what is analogous to the core self of our being.

Ironically this way to an intersubjective experience of union comes through a deep interior experience of our benign core self. We find the other through our interiority. We find the other through the containment of our character defenses and faults and ultimately the joy and love that lays waiting and underpins all that we are. The more we can experience our pride, egoistic separateness, malevolence, spite or any negative character trait fully and without defense, and still keep our eye on the prize of our loving core self within, the nearer we are to our divinity and union with the other.Hate is love outraged and fear is a separation from union. "The darker the devil the brighter the angel" is an old Kabalistic expression. It can be true in the work of psychoanalysis as well.

In Freud's (1915) "Instincts and their Vicissitudes" he spoke of the reversal of love into hate. The change of the content of an instinct into its opposite is observed in a single instance only-the transformation of love into hate (p.133) (italics author). In an effort to preserve his dual instinct theory Freud quickly suggested that hate is derived from the self's preservative instinct, asserting that it is of different origin than love born from libido. At the level of the ideal unambivalent core self, aggression is always a derivation of love. In Winnicottian terms aggression is, "an innocent, nonbelligerent desire for engagement".

Any character fault or malevolent feeling is a distortion of and permutation of a benign ideal form. The understanding that in any experience of the abject or malevolent within us the core self is available underneath and within the fault is an important factor. It can buoy us against the self hate that accrues from the negative affect and character faults. It also helps us keep our eye on the prize of the unfolding of our positive human nature.

Those of the Bionion tradition emphasize the containment of projections and beta elements and, finally, faith in the embrace of raw experiences of " $\mathrm{O}$ " in both their negative and positive forms.
In this thesis, I contend that in any "dark" experience of "O" a positive experience awaits liberation. The negative experiences of "O" are simply the dark night of the soul that is a preamble to the dawn of something positive emerging from darkness. Other authors cited in this thesis also suggest that our deepest nature is relational, positive, and morally compassed. Winnicot, Kohut, Bollas and Jung all postulate concepts analogous to a positive core self. However, their ideal dimension whilePlatonic, is not informed by the transcendence of Plotinian formalism.

Bionions steeped in the Platonic tradition, challenge the darkness of our human nature more directly but seem to stop there, with a sort of equivalence in the containment of positive and negative aspects of "O." I am suggesting more - that we go through the negative, by way of the embrace of the negative, and that we also look for the liberation of positive affects and experience from the darkness of our psyche. I am suggesting the negative can, through affect transformation,morph into positive affects and the experienceof a unitive nature.

\section{Comments on technique}

...every emotion is made of nothing but love. All pathology is merely physiology struggling under stressful ordeal. Anger, or grief, or jealousy or whatever painful emotion

is merely inhibited love struggling under stressful ordeal. Hate is hurt (hindered) love, deviltry is hurt (hindered) divinity, doubt is hurt (hindered) belief, fear is hurt (hindered) safety, guilt is hurt (hindered) innocence (Dorsey 1971a, p. 37).

Liberating the core self through the affect transformation of mourning is often a labor intensive process taking weeks and months. To dose a person with affective experience in such a way that its tolerance and regulation gain the upper hand and the transformation from negative to positive affective experience takes place requires tact and sensitivity. As treatment progresses however and one is able to tolerate and regulate affect, the experience can be accelerated and even in one session a critical degree of affect transformation may take place. For example, on one occasion I was leading a group that included a man who was very frightened of relationships with women. During one group he therapeutically ventilated his rage at a particular woman. He ranted as she stood in front of him, "You bitch, you nasty bitch I hate you and every one of you. You stand there and are smug and cut off, I hate you so much"... then he broke down and began to cry. You could see him melt into softer feelings, they were very hard for him to handle. As he was crying he began to say over and over again, "You are so beautiful, it hurts, I can't handle it. You are just so beautiful, so beautiful" He sobbed and sobbed. It was visible that he was able to make a profound feeling connection to and appreciation of this woman who seemed to be emblematic of all women to him. The breakthrough from his separateness into a rapturous amorous connection with this woman was very powerful but oddly difficult for him to experience. It may have seemed easier when he was "melting" to disrupt these powerful feelings because they were so intense. At this moment it was important to simply support this movement to the positive core affect. As we all were able stay grounded enough to tolerate the feelings everyone was moved emotionally andeventually a sense of calm and oneness seemed to overtake us.

This second phase of mourning which liberates softer affect and pain from hard feelings and hard pain contains within it a sub process of surrender. This surrender is part of the work as it requires 
affect tolerance on the part of the analyzand and analyst to affirm and stay with the positive as it can bring up fears of being swept away or of losing oneself. Here analysts may often become frightened of the "rapture" of surrender and want to explain it away as defensive. While a moment of surrender does not denotea completedtreatment, or mean one does not have issues to be dealt with, it is none- the- less a positive life affirming soul movement. Emanuel Ghent (2002) in part defines surrender thusly: It may be accompanied by a feeling of dread and death, and/or clarity, relief, even ecstasy. Its ultimate direction is the discovery of one's identity one's sense of self, one's sense of wholeness, even one's sense of unity with other living beings (p. 111).

Another example is of a fairly long first phase of treatment of experiencing negative affects and character faults which led to a final phase of transformation and a melting into truly loving ecstatic feelings. This patient was paraplegic with chronic pain. She had long felt bitter, suicidal and cheated by life. She has also felt that there was a glass wall between her and life and that it caused her to be a spectator of her own existence. When she "loved" her children it was because she knew she should, but she couldn't really feel it. After much work she began to have feelings of guilt that she should have been a better mother to her children and that she should stop blaming her parents for her lot in life. She developed periods in which she just cried and wanted her children to have better lives than they did and prayed that they knew happiness that she had never experienced. She began to feelecstatic-beyond herself. This all seemed strange and frightening to her. She stated that she didn't know what was happening to her and she felt odd and puzzled by this felt sense of warm positive feelings for her family and even her current caregivers. I stated: "What's happening is that after all this work your heart is opening up. You have broken through the glass wall that you have always talked about and you are really caring in much deeper ways and this is how it is coming to you. You are unthawing and your love is pouring out." Her response was to cry even more deeply and say: "I think that it's hard to stand. It feels so strong I don't know what to do with myself." I responded: "Just feel it. You don't have to do anything. If you cry off and on for days who cares"?

In subsequent sessions she confirmed the sense that what she was feeling was love instead of craziness and that it was a major turning point in her life. She said to me in a deeply compelling way"And you know what else? I so badly want to live now that I can't tell you; life feels so very meaningful to me. I feel so emotionally connected. I have never felt like this before". This affirmation and support led to a sense of surrender to positive affects which she previously felt were too strong to bear. Our workled to greater empathic relational abilities and an ecstatic sense of love and surrender to the wish for closeness and sense of union which exists as loving capacities within each of our core selves. The way to the other can be through the deepest longings of our inner selves.

\section{Dying into Process}

"Dying into process" is another aspect of this affective transformational work which leads to liberation of the core self. This is a dying into psychically painful feelingsthe patient has previously avoided. It is much like surrender but surrender implies a giving over to something elementally positive while dying into may feel more like a loss of part of our identity. A patient was working with her abject dependency on others' favorable feelings for her, in order for her to maintain a sense of well being.In many ways her psychic mortality felt dependent on others' acceptance of her.
She felt she would simply die if I, as the analyst, and others in her life did not like and accept her. This seems to accrue from an experience of shame - even mortification - when she is not affirmed. She would rather disappear into non-existence than face these feelings. She represses the dynamic and converts it into anxiety. To counteract this I encourage her to allow her exquisite sensitivity to others to remain on the surface of her consciousness and feel the abject sense of shame and mortification as best as she can in each moment. I do say it will feel much like you are dying in these moments because you believe your sense of being a worthwhile, valuable and loveable human being is at stake. Only by feeling this over and over again and managing the feelings and realizing that you don't actually die, although you feel that you want to, will this begin to fade. This dying process reminds me of Otto Rank's (1929) fear of and longing for death as an avoidance of life. He too spoke of death as an embrace of unity and surrender. Although Rank never spoke of a unitive reality below or within our negative affect and experience, this I would hope, is a technique he may have been fond of.

\section{Affirming the core self}

Affirming the existence of the core self and that its loving qualities are who a patient really is in his or her heart of hearts, can make tolerable the negative transference and negative affective states that seem otherwise unbearable. A particular patient, despite repetitive sessions, could notshake the hate he felt for me even though we both knew he valued me highly. One way in which he experienced this hate was by way of the transference in perceiving I was tiredand that I was withholding from him by not having as much energy. He would become very angry and feel I was neglecting him and rant at me for it. He also hated me because I had a good life and he did not, and he felt I was born with a silver spoon. He had fantasies of wanting to cut me up, torture me and burn me alive. Eventually hecould hardly stand all the hate hefelt and wonderedwhether he should stop analysis. I was worried about him and all the self loathing he had for feeling so hateful. He was in a great deal of pain. Wondering how I could help moderate his pain and tolerate his cruelty and sustain the analysis, I reframedhis cruelty as a distortion of longing for love and concern from me.

I saidto him: "All this hate is not the real you. You were deeply injured as a child and you felt utterly alone and now you want to make sure I am not going to jip you like your parents did. You also want to burn me alive to externalize all your pain and have me feel the pain you have felt for a change. This is a way to cope with your pain and try to change your history by punishing me. It can't work because the past is the past but please don't think this is just a character trait of yours that you were born with. You were born with longing for love and fulfillment like the rest of us but you had a lot of pain that caused you to feel cruel. Your pain that you register when you feel angry with me is also from the place in you that feels deeply connected with me. The core of youwhere you don't want to hurt me and are distressed by these feelings is the loving you, and I am ok even with your anger. If you stay with your authentic feelings your love will increase and eventually much of your cruelty will fade away. "God I hope so" he cried with a mixture of sadness and pleading. "I get so sick of myself that I can't stand it". This led to a sense of emotional softening in this session and we could feel a greater sense of self acceptance emerging.

As sessions passed, by reframing his anger in terms such as this, 
his inner cruelty faded and his self-esteem and loving capacities overtook his cruelty. Perhaps this might have happened if I didn't reframe his cruel feelings as love outraged, but my sense at the time, besides simply wanting him to feel better, was that if I didn't I might have lost him as he couldn't stand himself because of his cruelty.

\section{Conclusion}

In this paper I attempted to garner support in psychoanalytic literature for the concept of a core self with rich, empathic and transcendent relational capacities. I postulate itcontains a dual track sense of union with self and other. Using Plotinian philosophy I framed the core self with its unambivalent loving capacities as ultimately benign and ideal and as originary experience embedded in our deepest nature. I have also suggested that the containment of originary experience "O" with its ecstatic array of negative and positive affect should not be the ultimate aim of the psychoanalytic project. I suggest we appreciate that any negative, defensive or malevolent affect or character trait be understood as a permutation of a positive ideal version of that affect or trait. The negative is a shadow on the wall of Plato's allegorical cave. The dark night of the soul, so often spoken of in spiritual biographies and which can be found also in psychoanalytic practice, is but the containment of the malevolent permutations of originary experience before the loving sublime aspects of the permutation are affectively discovered. This experience of the positive, of the good within the bad, the sublime within the negative is the numinous dawn of the core self liberated from the dark shroud of character defenses and malevolent affect.

In the end, I hope that this treatise supports those psychoanalysts who endeavor to appreciate and embrace the unambivalent, ecstatic, positive, and loving aspects of our selves and being. These are the aspects of our core selves that touch the sublime, provide a sense of sacredness, and speak of who we can be.

\section{References}

[1] Arms, A. H. (1962) Plotinus, (as Translator) Allen \& Unwin, 1953, Collier, 1962.

[2] Bion, W. R. (1962). Learning from Experience. London: W. Heinemann.

[3] Bion, W. R. (1963). Elements of Psychoanalysis.London: W. Heinemann.

[4] Bion, W. R. (1965). Transformations. London: W. Heinemann.

[5] Bion, W. R. (1966). Catastrophic change. Scientific Bulletin of the British
Psychoanalytic Society, 5

[6] Bion, W. R. (1970). Attention and Interpretation London: Tavistock.

[7] Bollas, C. (1989). Forces of Destiny: Psychoanalysis and the Human Idiom. London: Free Association Books.

[8] Bollas, C. (1999). The Mystery of Things. London: Routledge.

[9] Bion, W. (1970). Attention and Interpretation. New York: Basic Books.

[10] Eigen, M. (1983) Dual union or undifferentiation? A critique of Marion Milner's view of the sense of psychic creativeness. International Review of Psychoanalysis 10: 415-428.

[11] Eigen, M. (1992). Coming Through the Whirlwind. Wilmette, IL: Chiron Publications.

[12] Eigen, M. (1993). The Electric Tightrope. Northvale, NJ: Jason Aronson.

[13] Eigen, M. (1995). Reshaping the Self. Madison, CN: Psychosocial Press/International Universities Press.

[14] Eigen, M. (1998). The Psychoanalytic Mystic. London: Free Association Books.

[15] Eigen, M. (2004). The Sensitive Self. Midletown, CT: WesleyanUniversity Press.

[16] Freud, S. (1915) "Instincts and their vicissitudes". Standard Edition 14: 117140.

[17] Freud, S. (1920). Beyond the Pleasure Principle. Standard Edition 18: 3-64.

[18] Gargiulo, G. (2004) Psyche, Self and Soul: Rethinking Psychoanalysis, the Self and Spirituality. Philadelphia, PA: Whurr Publishers.

[19] Ghent, E. (2002). Wish, Need, Drive :Motive in Light of Dynamic Systems Theory and EdelmansSelectionist Theory. Psychoanalytic Dialogues. 12: 763-808.

[20] Goldstein, S. The Parallel Paths of Psychoanalysis and Spirituality: Convergences, Divegences, Transformation. Psychoanalytic Perspectives. 6 (1): 45-66.

[21] Greenberg, J. R. and Mitchell, S. A.(1983). Object Relations in Psychoanalytic Theory. Cambridge, MA: HarvardUniversity Press.

[22] Grotstein, J. S. (1979) Who is the Dreamer who Dreams the Dream and who is the dreamer who understands it- A Psychoanalytic Inquiry into the Ultimate Nature of Being. Contemporary Psychoanalysis 15: 110 - 169.

[23] Grotstein, J. S. (1979) Demonical Possession, Splitting and the Terror of Joy: A Psychoanalytic Inquiry into the Negative Therapeutic Reaction, Unanalizability, and PsychoticStates. Contemporary Psychoanalysis 17: 501536.

[24] Grotstein, J. S. (2000) Who is the Dreamer who Dreams the Dream? A Study of Psychic Presences. Hillsdale, NJ\&London: The Analytic Press.

[25] Jung, C. G. (1953). Two Essays on Analytical Psychology. Princeton, NJ: PrincetonUniversity Press.

[26] Kohut, H. (1977). The Restoration of the Self. New York: International Universities Press.

[27] Kohut, H. (1984). How Does Analysis Cure?Chicago: University of Chicago Press.

[28] Krystal, H. (1988). Integration and self-healing: Affect, trauma, and alexithymia. Ann Arbor, MI: Psychoanalytic Press.

[29] Lacan, J. (1977) Ecrits. Translated by A. Sheridan. New York: Norton.

[30] Milner, M. B. (1952) Aspects of symbolism in the comprehension of notself. International Journal of Psychoanalysis 33:181-194.

[31] Molino, A. (1997). Freely Associated.London: Free association Books.

[32] Rank, O. (1929). Beyond Psychoanalysis.Psychoanalytic Review, 16; 1-11.

[33] Sollars, F.R. (2004). Mourning Trauma, and Working Through. Psychoanalytic Review, 91: 201-219.

[34] Winnicott, D.W. (1965). The Maturational Process and the Facilitating Environment. New York: International Universities Press.

[35] Winnicott, D. W. (1971) Playing with Reality. New York: Basic Books. 